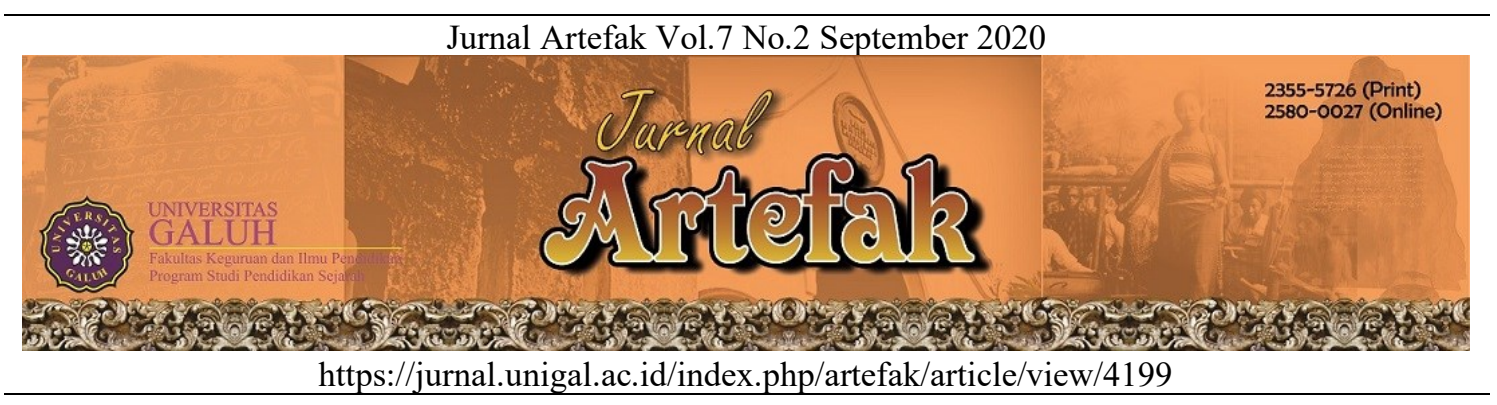

\title{
NILAI-NILAI KEARIFAN LOKAL LEUWEUNG GEDE KAMPUNG KUTA CIAMIS DALAM MENGEMBANGKAN GREEN BIHAVIOR UNTUK MENINGKATKAN KARAKTER MAHASISWA
}

\author{
Dewi Ratih ${ }^{1}$, Aan Suryana ${ }^{2}$ \\ Universitas Galuh Ciamis, Indonesia \\ E-mail: dewiratih@unigal.ac.id ${ }^{1}$, aansuryana64@gmail.com² \\ Sejarah Artikel: Diterima Juli 2020, Disetujui Agustus 2020, Dipublikasikan September 2020
}

\begin{abstract}
Abstrak
Tujuan penelitian ini adalah untuk mengetahui peningkatan karakter siwa dengan menggunakan nilai-nilai kearifan lokal Leuweung Gede Kampung Kuta. Penelitian ini dilakukan dengan menggunakan metode Penelitian Tindakan Kelas (Classroom Reseach). Pengumpulan data dilakukan melalui observasi, wawancara, pemberian tes (pre dan post test). Hasil penelitian menunjukkan bahwa nilai-nilai kearifan lokal Hutan Leuweung Gede mampu meningkatkan karakter siswa, yang dibuktikan dengan hasil angket yang meningkat dari setiap siklus, yaitu dari 50\% menjadi 80\%. Diantara nilai-nilai kearifan lokal Hutan Leuweung Gede Kampung Kuta adalah nilai keagamaan, bahasa, etika, menjaga lingkungan, sistem teknologi dan lainnya.
\end{abstract}

Kata Kunci: nilai-nilai; kearifan lokal; green behavior; belajar sejarah; karakter

\begin{abstract}
I The purpose of this study was to determine the improvement of the character of the shiva by using the local wisdom values of Leuweung Gede Kampung Kuta. This research was conducted using the Classroom Research method (Classroom Research). Data collection was carried out through observation, interviews, giving tests (pre and post-test). The results showed that the values of local wisdom in the Leuweung Gede Forest were able to improve the character of students, as evidenced by the increasing results of the questionnaires from each cycle, from $50 \%$ to $80 \%$. Among the local wisdom values of the Leuweung Gede Forest in Kampung Kuta are religious values, language, ethics, protecting the environment, technology systems and others.
\end{abstract}

Keyword: values; local culture; green behavior; studying history; character

\section{PENDAHULUAN}

Kampung Adat Kuta merupakan sebuah daerah yang berada di Desa Karangpaninggal, Kecamatan Tambak-sari, Kabupaten Ciamis. Di kampung ini masih menjaga dan memelihara adat dan tradisi yang menurut kepercayaan masyarakat setempat tidak bisa dihilangkan. Salah satunya, adat dan tradisi dalam menjaga lingkungan. Masyarakat Kampung Kuta memiliki aturan yang sangat ketat untuk menjaga kelestarian alamnya, seperti dalam menjaga kelestarian hutan Leuweung Gede yang merupakan sumber kehidupan bagi masyarakat tersebut. Hutan Leuweung Gede merupakan tempat yang dianggap keramat oleh masyarakat Kampung Kuta. Maksud dari kata keramat disini adalah bahwa tidak semua orang bebas untuk masuk dan keluar ke hutan ini. Ada aturan-aturan yang harus diikuti oleh pengunjung untuk bisa masuk ke hutan Leuweung Gede. Mulai dari hari untuk kunjungan, pakaian yang harus 
digunakan, bahasa yang dipakai ketika berada di dalam hutan, hal-hal yang boleh dan tidak boleh dilakukan ketika berada di dalam hutan, dan lain-lain. Aturan-aturan yang dibuat selalu dikaitkan dengan hal-hal yang mistis. Namun, kalau dipahami lebih dalam aturan-aturan tersebut memiliki makna yang sama dengan aturan yang ada pada umumnya. Tujuannya adalah untuk menjaga kelestarian hutan dari tangan-tangan jahil manusia yang tidak bertanggung jawab. Dari aturan yang telah dibuat, maka lahirlah suatu nilai kearifan lokal yang sangat penting untuk diteladani dan diterapkan oleh generasi penerus bangsa.

Berdasarkan penjelasan di atas, nilainilai kearifan lokal hutan Leuweung Gede memiliki urgensi yang sangat tinggi untuk diketahui dan dipelajari oleh generasi penerus. Hal ini dikarenakan nilai-nilai kearifan lokal memiliki peranan dalam dunia pendidikan terutama untuk pembentukan karakter generasi penerus. Sesuai dengan ungkapan bahwa bangsa yang maju adalah bangsa yang memiliki karakter yang kuat. Dimana nilainilai karakter tersebut adalah nilai-nilai yang digali dari khasanah budaya yang selaras dengan karakteristik masyarakat setempat (kearifan lokal) dan bukan "mencontoh" nilainilai bangsa lain yang belum tentu sesuai dengan karakteristik dan kepribadian bangsa tersebut. Budaya yang digali dari kearifan lokal bukanlah penghambat kemajuan dalam era global, namun justru menjadi filter budaya dan kekuatan transformasional yang luar biasa dalam meraih kejayaan bangsa. Oleh karena itu, menggali nilai-nilai kearifan lokal merupakan upaya strategis dalam membangun karakter bangsa di era global. Kearifan lokal dalam bahasa asing sering dikonsepsikan sebagai kebijakan setempat (local wisdom), pengetahuan setempat (local knowledge) atau kecerdasan setempat (local genious). Kearifan lokal juga dapat dimaknai sebuah pemikiran tentang hidup. Pemikiran tersebut dilandasi nalar jernih, budi yang baik, dan memuat halhal positif. Kearifan lokal dapat diterjemahkan sebagai karya akal budi, perasaan mendalam, tabiat, bentuk perangai, dan anjuran untuk kemuliaan manusia (Wagiran, 2012: 329330).

Salah satu nilai-nilai kearifan lokal yang perlu dikembangkan dan disosialisasikan adalah nilai-nilai kearifan lokal hutan Leuweung Gede yang ada di Dusun Kuta, Kabupaten Ciamis. Diantara nilai-nilai kearifan lokal dari hutan Leuweung Gede kampung adat Kuta adalah nilai keagamaan, bahasa, etika, menjaga lingkungan, dan sistem teknologi (Ratih dan Suryana: 2020).

Namun, kenyataannya pentingnya nilainilai kearifan lokal hutan Leuweung Gede masih belum dipahami secara menyeluruh oleh generasi muda. Hal ini berdasarkan hasil penelitian yang menunjukan $50 \%$ siswa tidak mengetahui nilai-nilai kearifan lokal hutan Leuweung Gede.

Salah satu cara supaya nilai kearifan lokal yang terdapat di hutan Leuweung Gede Kampung Kuta, Kabupaten Ciamis dapat diteladani dan diterapkan oleh generasi selanjutnya adalah melalui aplikasi nilai-nilai kearifan lokal dalam kegiatan pembelajaran. Dalam hal ini, peneliti melakukan kegiatan pembelajaran dengan mengkolaborasikan materi yang ada di mata kuliah sejarah lokal dengan nilai-nilai kearifan lokal hutang Leuweung Gede, sehingga diharapkan setelah menerapkan nilai-nilai kearifan hutan Leuweung Gede karakter mahasiswa meningkat.

\section{METODE PENELITIAN}

Penelitian ini menggunakan metode Penelitian Tindakan Kelas (PTK). Penelitian Tindakan Kelas atau dalam bahasa Inggris dikenal dengan classroom action research sejak lama berkembang di negara-negara maju seperti Inggris. Australia dan Amerika. Dalam PTK guru dapat meneliti sendiri terhadap praktek pembelajaran yang dilakukan di kelas. Dengan PTK, guru dapat melakukan penelitian terhadap siswa dari berbagai aspek 
selama proses pembelajaran berlangsung. Penelitian Tindakan Kelas juga dapat menjebatani kesenjangan antara teori dan praktek pendidikan. Hal ini dapat terjadi dikarenakan setelah seseorang melakukan penelitian terhadap kegiatannya sendiri, di kelasnya sendiri, dengan melibatkan siswanya sendiri, melalui suatu tindakan yang direncanakan, dilaksanakan dan dievaluasi, guru tersebut akan memperoleh umpan balik yang sistematis mengenai apa yang selama ini selalu dilakukan dalam kegiatan pembelajarannya. Dengan demikian guru dapat membuktikan apakah suatu teori pembelajaran dapat diterapkan dengan baik di kelas yang dimilikinya. Setiap penelitian memiliki karakteristiknya sendiri-sendiri. Bagi PTK karakteristik yang menonjol adalah dalam hal masalah yang akan diteliti. Masalah yang diangkat dan akan dipecahkan melalui PTK harus selalu berangkat dari permasalahan praktek pembelajaran sehari-hari yang dihadapai oleh guru. PTK akan dapat dilaksanakan oleh guru jika sejak awal guru menyadari adanya persoalan yang terkait dengan proses dan produk pembelajaran yang dihadapinya di kelas. Karakteristik kedua adalah bahwa PTK merupakan penelitian tindakan kolaboratif yaitu penelitian yang melibatkan orang lain untuk bersama-sama menemukan dan merumuskan persoalan pembelajaran di kelas. Dalam konteks ini guru dapat berkolaborasi dengan dosen FKIP untuk melakukan penelitian tindakan kelas. Tujuan penelitian tindakan kelas terkait erat dengan keinginan seseorang untuk meningkatkan dan atau memperbaiki praktek pembelajaran di kelas. Penelitian ini seharusnya dilakukan oleh para guru, karena para guru adalah orang yang secara langsung berhadapan dengan permasalahan-permasalahan yang ada di kelasnya. Penelitian tindakan kelas merupakan cara strategis bagi guru untuk memperbaiki proses pembelajaran di kelas (Sumini, $\mathrm{Tt}$ ).

Selanjutnya, penelitian tindakan (action research) termasuk dalam ruang lingkup penelitian terapan (applied research) yang menggabungkan antara pengetahuan, penelitian dan tindakan. Action research mempunyai kesamaan dengan penelitian: participatory research, collaborative inquiry, emancipatory research, action learning, dan contextual action research. Secara sederhana, action research merupakan "learning by doing" yang di terapkan dalam konteks pekerjaan seseorang. Pada saat seseorang bekerja, dia selalu menghasilkan ide-ide baru yang diwujudkan dalam tindakan untuk memperbaiki proses maupun hasil pekerjaannya. Menurut O'Brien (2001) penelitian tindakan dilakukan ketika sekelompok orang (siswa) diidentifikasi permasalahannya, kemudian peneliti (guru) menetapkan suatu tindakan untuk mengatasinya. Selama tindakan berlangsung, peneliti melakukan pengamatan perubahan perilaku siswa dan faktor-faktor yang menyebabkan tindakan yang dilakukan tersebut sukses atau gagal. Apabila peneliti merasa tindakan yang dilakukan hasilnya kurang memuaskan maka akan dicoba kembali tindakan kedua dan seterusnya. Dalam PTK, jarang ada keberhasilan yang dapat dicapai dalam satu kali tindakan, oleh sebab itu PTK sering dilakukan dalam beberapa siklus tindakan. Pengaruh action research kemudian dipelajari dan dilaporkan secara mendalam dan sistematis (Mulyatiningsih: Tt).

\section{HASIL PENELITIAN DAN PEMBAHASAN}

\section{Perencanaan Pembelajaran Sejarah Lokal dengan Menggunakan Nilai-Nilai Kearifan Lokal Hutan Leuweung Gede}

Sebelum melaksanakan kegiatan pembelajaran dosen dan peneliti melakukan tahapan perencanaan agar pembelajaran sesuai dengan yang diharapkan. Penelitian tindakan kelas ini dilaksanakan pada mahasiswa tingkat I semester 2 Prodi Pendidikan Sejarah. Penelitian ini bertujuan untuk mengatasi masalah yang dihadapi mahasiswa ketika 
pembelajaran di kelas yaitu mengenai rendahnya pemahaman nilai-nilai kearifan lokal hutan Leuweung Gede yang berdampak pada peningkatan karakter mahasiswa. Nilai tertinggi di tingkat I sebelum diadakan tindakan adalah 75 dan nilai terendahnya 36 . Melihat kondisi ini, maka diperlukan tindakan supaya permasalahannya dapat diatasi. Untuk mata kuliah sejarah lokal di tingkat I ini dipegang oleh dosen, yaitu Dewi Ratih, S.Pd, M.Pd yang dalam penelitian ini dijadikan sebagai dosen mitra. Pembelajaran sejarah lokal dengan menggunakan nilai-nilai kearifan lokal hutan Leuweung Gede masih belum banyak dilaksanakan dalam kegiatan perkuliahan, sehingga melalui penelitian ini akan diaplikasikan pembelajaran sejarah lokal dengan menggunakan nilai-nilai kearifan lokal hutan Leuweung Gede untuk meningkatkan karakter siswa.

Pada proses pembelajaran di kelas dosen menyiapkan hal-hal yang berkaitan dengan materi khususnya nilai-nilai kearifan lokal dari hutan Leuweung Gede, mulai dari RPS, instrumen penelitian, dan lain-lain. Sealnjutnya, dosen membagi mahasiswa menjadi 6 kelompok, dimana masing-masing kelompok mendiskusikan dan menganalisis nialai-nilai kearifan lokal yang terdapat di hutan Leuweung Gede.

Sebelum pelaksanaan kegiatan pembelajaran pada siklus I, dosen diberikan pemahaman terlebih dahulu mengenai penggunaan niali-nilai kearifan lokal hutan Leuweung Gede dalam pembelajaran sejarah lokal. Adapun pada kegiatan perencanaan ini, peneliti menemukan beberapa temuan, diantaranya:

1. Dosen menyusun RPS sebelum proses perkuliahan dilaksanakan, dan RPS tersebut dibuat berdasarkan RPS tahun sebelumnya, sehingga dosen tidak mengalami perubahan dalam penyusunan isi RPS.

2. Dosen melakukan pembelajaran di kelas dengan metode ceramah, tanya jawab, dan diskusi.
3. Dosen masih belum menggunakan nilainilai kearifan lokal yang dekat dengan lingkungan mahasiswa dalam proses pemeblajaran.

Setelah peneliti menemukan beberapa temuan pada kondisi di atas dimana hal ini dapat berimbas pada peningkatan karakter mahasiswa, maka perencanaan pembelajaran dengan menggunakan nilai-nilai kearifan lokal hutan Leuweung Gede pada siklus dalam penelitian ini diantaranya sebagai berikut:

1. Menetapkan pelaksanaan penelitian yang dilakukan dari bulan Pebruari 2019 sampai dengan bulan Mei 2019.

2. Menentukan kelas sebagai objek penelitian, yaitu mahasiswa tingkat I semester II.

3. Sebelumnya peneliti berdiskusi terlebih dahulu dengan dosen mitra apakah dosen mitra sudah mengerti mengenai nilai-nilai kearifan lokal hutan Leuweung Gede, sehingga diharapkan dosen dapat menyusun RPS.

4. Menyusun Rencana Pembelajaran Semester (RPS) dan didiskusikan bersama dosen mitra.

5. Menetapkan sumber pelajaran yaitu dengan menggunakan nilai-nilai kearifan lokal hutan Leuweung Gede.

6. Metode pendukung pembelajaran, yaitu metode ceramah, diskusi, dan tanya jawab.

7. Menetapkan tujuan yang ingin dicapai sebagai bahan penilaian, analisis dan refleksi, yaitu mahasiswa mampu:

a. Menjelaskan makna dari nilai.

b. Menjelaskan arti dari kearifan lokal

c. Menjelaskan tentang nilai-nilai kearifan lokal di hutan Leuweung Gede, Kampung adat Kuta, Kabupaten Ciamis.

8. Membagi jumlah kelompok menjadi 4 kelompok:
a. Kelompok I:
b. Kelompok II:
c. Kelompok III:
d. Kelompok IV:

9. Menyusun format penilaian 
Berdasarkan hasil pengamatan peneliti pada siklus I, setelah dibuat perencanaan, maka diperoleh hasil, yaitu perencanaan pembelajaran siklus I masih banyak yang harus diperbaiki dan harus dilaksanakan tindakan selanjutnya, karena hasil yang didapat belum sesuai dengan tujuan yang telah ditetapkan seperti pembagian waktu yang kurang tepat, sehingga kegiatan pembelajaran keluar dari apa yang telah ditetapkan, dan belum adanya pelaksanaan yang baik terutama pada tahap elaborasi dan konfirmasi.

Dari hasil di atas menunjukan bahwa pelaksanaan pembelajaran belum berhasil, sehingga tindakan penelitian dilanjutkan siklus II dengan menerapkan perbaikan sesuai hasil refleksi. Hasil refleksi tersebut diwujudkan dalam tindakan perencanaan pembelajaran dengan menggunakan nilai-nilai kearifan lokal hutan Leuweung Gede sebelum proses belajar mengajar dimulai. Sebelum menyusun perencanaan pembelajaran, peneliti menemukan beberapa temuan dari hasil siklus I, yaitu:

1. Dosen masih tergantung pada RPS tahun yang lalu.

2. RPS yang dibuat belum sepenuhnya baik, karena langkah-langkah pembelajaran dengan menggunakan nilai-nilai kearifan lokal belum sepenuhnya bisa dilaksanakan.

3. Dosen masih dominan di dalam kelas.

4. Mahasiswa masih kurang antusias dalam berdiskusi dan menganalisis nilai-nilai kearifan lokal hutan Leuweung Gede.

5. Belum optimal dalam pengelolaan waktu yang dilakukan oleh dosen.

6. mahasiswa masih banyak yang belum mengikuti kegiatan pembelajaran sejarah lokal secara tepat waktu.

Setelah menemukan beberapa temuan pada siklus I dari hasil refleksi, masih ada yang perlu diperbaiki, maka peneliti dengan dosen melakukan diskusi untuk kegiatan siklus II, dengan tujuan agar hasil belajar lebih baik dibandingkan siklus I. Berikut merupakan deskripsi perencanaan pada siklus II:
1. Materi ajar yang dipilih yaitu nilai-nilai kearifan lokal dan dalam hal ini yang dipilih adalah nilai-nilai kearifan lokal hutan Leuweung Gede.

2. Mahasiswa mampu untuk: Menganalisis nilai-nilai kearifan lokal hutan Leuweung Gede yang dikaitkan dengan karakter.

3. Menyusun Rencana Pembelajaran Semester (RPS).

4. Metode pendukung pembelajaran yaitu metode ceramah, diskusi, dan tanya jawab.

5. Dosen bertindak sebagai motivator dan fasilitator.

6. Dosen harus bisa memberikan pendapat yang positif, sehingga mahasiswa lebih bersemangat dalam melakukan pembelajaran.

Setelah perencanaan tersebut dilaksanakan pada siklus II dan hasilnya sudah lebih baik dibandingkan dengan siklus I serta dianggap sudah sesuai dengan tujuan yang diharapkan, yaitu dosen dan mahasiswa lebih memahami nilai-nilai kearifan lokal hutan Leuweung Gede dan kaitannya dengan peningkatan karakter, dalam proses pembelajaran dosen sudah dapat mengawali pembelajaran dengan baik, serta dalam tahap elaborasi sudah berjalan sesuai dengan yang direncanakan.

Dengan demikian penelitian dicukupkan sampai dengan siklus II, karena dianggap telah mencapai target yang diinginkan, yaitu $85 \%$ untuk peningkatan karakter mahasiswa. Dalam penelitian ini berlangsung selama 2 siklus, dimana dalam setiap siklusnya terdiri dari tahapan perencanaan, pelaksanaan, pengamatan, dan refleksi.

Setiap pertemuan terdiri dari 45 menit untuk I jam pelajaran, sedangkan peneliti menggunakan waktu $2 \times 45$ menit, yaitu untuk dua jam pelajaran. Pada pertemuan pertama di siklus I, dosen memperkenalkan nilai-nilai kearifan lokal dari hutan Leuweung Gede Kampung adat Kuta Ciamis yang di memiliki peranan penting dalam meningkatkan karakter mahasiswa. Pertemuan kedua dalam siklus I 
dosen sudah menggunakan nilai-nilai kearifan lokal hutan Leuweung Gede seperti nilai nilai keagamaan, bahasa, etika, menjaga lingkungan, sistem teknologi.

Pelaksanaan Pembelajaran Sejarah Lokal dengan Menggunakan Nilai-Nilai Kearifan Lokal Hutan Leuweung Gede

\section{Tindakan Siklus I}

Pelaksanaan tindakan siklus I dipaparkan hasil penelitian yang terdiri dari; a) perencanaan, b) pelaksanaan, c) pengamatan, d) refleksi.

\section{a. Perencanaan (planing)}

Aktifitas perencanaan pada siklus I diantaranya:

1) Menentukan kelas sebagai objek penelitian, yaitu tingkat I semester II.

2) Melakukan observasi dengan observer mengenai kegiatan pembelajaran.

3) Mendiskusikan dan menentukan materi berdasarkan silabus dan RPS.

4) Mempersipakan perangkat pembelajaran

5) Menentukan alokasi waktu, yaitu $2 \times 45$ menit.

\section{b. Pelaksanaan}

Pelaksanaan kegiatan belajar pembelajaran siklus I, dilaksanakan sebanyak 2 kali di tingkat I semester II yang berjumlah 20 orang. Disini peneliti sebagai pengamat dan dosen mitra sebagai objek yang diamati dengan menggunakan nilai-nilai keraifan lokal hutan Leuweung Gede. Adapun proses pembelajarann mengacu pada Rencana Pembelajaran Semester (RPS) yang telah dipersiapkan peneliti dan dosen mitra sebelumnya.

Pertemuan I, pelaksanaan pembelajaran dengan mengikuti langkahlangkah pembelajaran sebagai berikut: pendahuluan, kegiatan inti, dan penutup.

Pendahuluan, dosen melakukan apersepsi yaitu memeriksa kehadiran dan persiapan mahasiswa dalam mengikuti pembelajaran. Selanjutnya dosen memberikan motivasi dan menyampaikan tujuan pembelajaran yang harus dicapai mahasiswa setelah mengikuti kegiatan pembelajaran, yaitu melalui kegiatan pembelajaran sejarah lokal diharapkan mahasiswa mampu mendeskripsikan nilainilai kearifan lokal apa saja yang bisa diambil dari hutan Leuweung Gede.

Kegiatan inti pada pembelajaran yang dilaksanakan sekitar 45 menit, yaitu pada tahap eksplorasi, dosen terlebih dahulu membagi mahasiswa menjadi empat kelompok secara heterogen untuk melakukan kegiatan diskusi. Sebelum diskusi dimulai dosen memberikan penjelasan singkat tentang materi sejarah lokal selama 15 menit dan mahasiswa memperhatikan penjelasan yang disampaikan oleh dosen.

Tahap elaborasi, dosen memberikan kesempatan kepada mahasiswa untuk belajar secara tim sesuai dengan kelompok yang telah dibentuk. Kegiatan mahasiswa dalam diskusi adalah mencari dan menganalisis niali-nilai kearifan lokal hutan Leuweung Gede. Setiap mahasiswa dalam kelompok mempunyai tanggung jawab untuk membimbing teman anggotanya yang belum memahami materi, sehingga semua anggota menguasai materi dan masing-masing memberikan kontribusi. Selanjutnya mahasiswa mempresentasikan hasil diskusi kelompok serta melaporkannya pada dosen. Tahap konfirmasi, dosen sebagai fasilitator meluruskan jawaban dari pertanyaan mahasiswa yang menghadapi kesulitan dalam menyelesaikan soal diskusi.

Penutup, kegiatan penutup pada pembelajaran dilaksanakan sekitar 5 menit, dosen bersama-sama mahasiswa membuat kesimpulan dari materi yang telah diajarkan. Selanjutnya dosen memberikan penilaian dan memberikan penghargaan kepada team atau kelompok yang mendapat skor tertinggi. 
Pertemuan ke II dilaksanakan pada hari Selasa tanggal 17 Maret 2019. Sebelum mahasiswa unjuk tugas kelompoknya, dosen melakukan apersepsi selama 5 menit, yaitu memeriksa kehadiran mahasiswa dan persiapan setiap kelompok. Selanjutnya penyampaian tujuan pembelajaran, yaitu mahasiswa mampu mendeskripsikan dan memahami nilai-nilai kearifan lokal hutan Leuweung Gede.

Kegiatan inti dilaksanakan sekitar 60 menit, yaitu tahap eksplorasi, dosen menggunakan nilai-nilai kearifan lokal hutan Leuweung Gede dalam proses pembelajaran serta kaitannya dengan niali karakter yang berperan penting bagi mahasiswa, memfasilitasi terjadinya interaksi antar mahasiswa dengan mahasiswa lainnyasiswa, mahasiswa dengan dosen, serta melibatkan mahasiswa secara aktif dalam setiap kegiatan pembelajaran.

Tahap elaborasi, dosen memfasilitasi setiap kelompok untuk unjuk tugas dan kelompok lain mendengarkannya. Setiap kelompok diberi waktu 10 menit untuk menyampaikan hasil kerjanya. Setelah selsai kelompok 1, dilanjutkan presentasi kelompok 2, dilanjutkan dengan kelompok 3, dan terakhir kelompok 4. Dalam penyampaian diskusi tiap kelompok hanya diwakili oleh anggotanya maksimal 2 orang. Selanjutnya dosen memberikan kesempatan pada mahasiswa untuk berfikir, menganalisis materi yang disampaiakan. Memfasilitasi mahasiswa dalam pembelajaran, memfasilitasi mahasiswa berkompetensi secara sehat supaya karakter mahasiswa meningkat.

Tahap konfirmasi, mahasiswa memberikan umpan balik positif dan penguatan dalam bentuk lisan, tulisan, dan isyarat kepada mahasiswa secara individu atau kelompok.

Kegiatan penutup, yaitu dosen dan mahasiswa secara bersama-sama mengambil kesimpulan dari materi yang telah diajarakan melalui pembelajaran kelompok. Selanjutnya dosen melakukan penilaian terhadap kegiatan yang telah dilakukan yaitu dengan memberikan penghargaan kepada setiap team.

Dalam penelitian ini peneliti menggunakan instrumen berupa angket karakter untuk mengetahui peningkatan karakter mahasiswa melalui penggunaan nilai-nilai kearifan lokal hutan Leuweung Gede. Dalam menentukan skor dari angket tersebut, sistem penskoran yang digunakan adalah skala Likert dengan 4 pilihan jawaban yaitu Sangat setuju (SS), Setuju (S), Tidak setuju (TS), dan Sangat tidak setuju (STS). Untuk pernyataan positif skala yang digunakan adalah 4, 3, 2, dan 1 sedangkan untuk penyataan negatif $1,2,3$, dan 4.

\section{c. Pengamatan}

Peneliti sebagai pengamat, melakukan pengamatan dengan mengisi lembar observasi untuk proses pembelajaran yang dilakukan dosen dan lembar observasi untuk kegiatan pembelajaran mahasiswa secara individual maupun kelompok yang telah dipersiapkan sebelumya oleh peneliti. Pada pertemuan pertama di siklus I, pembelajaran masih belum menggunakan niali-nilai kearifan lokal hutan Leuweung Gede. Pembelajaran berlangsung sekitar 30 menit.

Dosen belum bisa mengarahkan mahasiswa untuk lebih konsentrasi di dalam kelas. Sedangkan pertemuan ke II, pembelajaran dengan menggunakan nilainilai kearifan lokal hutan Leuweung Gede melalui diskusi kelompok yang terdiri dari 4 kelompok. Dalam pelaksanaan pembelajaran sudah cukup baik, walaupun diskusi masih didominasi oleh mahasiswamahasiswa yang memiliki kemampuan akademik yang lebih. 


\section{d. Refleksi}

Dalam pelaksanaan kegiatan pembelajaran diperoleh informasi dari hasil pengamatan peneliti sebagai berikut:

1) Pada pertemuan pertama dosen tidak menjelaskan Kompetensi Dasar dan tujuan pembelajaran, serta kurang memberikan motivasi terhadap mahasiswa, sehingga mahasiswa kurang antusias dan kurang aktif selama kegiatan pembelajaran berlangsung.

2) Dosen masih mendominasi dalam menjelaskan materi, sehingga belum bisa menggunakan waktu dengan baik.

3) Dosen tidak melakukan kegiatan penutup serta tidak menyimpulkan materi, karena dosen masih merasa canggung dengan kehadiran peneliti yang mengamati proses kegiatan belajar mengajar.

4) Dalam kegiatan diskusi masih didominasi oleh mahasiswa yang memiliki kemampuan akdemis lebih.

5) Pada diskusi kelompok keterlibatan kelompok-kelompok masih kurang. Hanya ada beberapa mahasiswa yang rajin yang mengerjakan tugas kelompok dengan baik.

6) Peranan dosen pun masih dominan dalam memberikan penjelasan materi.

7) Pada waktu berlangsung Post Test masih banyak mahasiswa yang kurang percaya diri, sehingga hasil yang diperoleh masih jauh dari yang diharapkan, dari 20 mahasiswa yang tuntas hanya 10 orang, dengan nilai terendah 40 dan nilai tertinggi 80 .

\section{Tindakan Siklus II}

Pembelajaran pada siklus I belum mencapai tujuan yang diharapkan, maka masih banyak yang perlu diperbaiki. Pada siklus II masih menggunakan nilai-nilai kearifan lokal hutan Leuweung Gede.

\section{a. Perencanaan (Planning)}

Berdasarkan refleksi terhadap pelaksanaan tindakan siklus pertama, peneliti dan dosen mitra mengadakan diskusi balikan untuk memperbaiki pelaksanaan tindakan siklus I, dan memberikan dorongan kepada dosen yang dijadikan model pembelajaran dengan menggunakan nilai-nilai kearifan lokal hutan Leuweung Gede. Bahwa kehadiran peneliti bukanlah sebagai pengawas yang akan mengevaluasi atau mencari kesalahan, tetapi untuk menjadikan mitra dalam penelitian tindakan kelas dengan diskusi dan mencari solusi terhadap hal-hal yang perlu diperbaki dalam pembelajaran dengan menggunakan nilai-nilai kearifan lokal hutan Leuweung Gede. Hal ini disampaikan dengan maksud untuk memberikan kepercayaan kepada dosen yang dijadikan model pembelajaran, jangan sampai kehadiran peneliti menimbulkan rasa canggung, segan, dan malu. Kemudian peneliti merencanakan siklus ke II, dari hasil diskusi ini diperoleh kesepakatan sebagai berikut:

1) Dosen mengajar sesuai dengan langkah-langkah pembelajaran yang terdapat dalam Perencanaan Pembelajaran Semester (RPS).

2) Dosen tidak harus memberikan penjelasan materi secara panjang lebar, supaya waktu yang direncanakan dalam RPS bisa berjalan sebagaimana mestinya.

3) Dosen bertindak sebagai motivator dan fasilitator dalam pembelajaran, memberikan kesempatan dan penjelasan yang sama kepada mahasiswa yang memberikan pertanyaan agar karakter mahasiswa meningkat.

4) Diakhir pembelajaran agar dosen menutup pembelajaran dengan menyimpulkan materi pembelajaran.

5) Akan diadakan tindakan siklus II. 


\section{b. Pelaksanaan (Action)}

Tinadakan siklus kedua, dilaksanakan sebanyak dua kali pertemuan, yang terdiri dari pendahuluan, kegiatan inti, penutup.

Pendahuluan, dosen melakukan apersepsi selama 10 menit, yaitu memeriksa kehadiran mahasiswa dan persiapan mereka dalam mengikuti pembelajaran. Memberikan motivasi dan penyampaian tujuan sesuai dengan Kompetensi dasar yang telah ditetapkan.

Kegiatan inti dalam pelaksanaan pembelajaran dilaksanakan selama 30 menit, yaitu dengan menggunnakan metode yang sesuai dengan karakteristik mahasiswa yang meliputi: Tahap eksplorasi, Dosen menggunakan nilai-nilai kearifan lokal hutan Leuweung Gede.

Tahap elaborasi. Pada saat menjelaskan nilai-nilai kearifan lokal salah satunya yang terdapat di hutan Leuweung Gede supaya mahasiswa lebih termotivasi dalam belajar serta mampu meningkatan karakter mereka. Dosen memberi kesempatan mahasiswa untuk berfikir dan menganalisis tentang nilai-nilai kearifan lokal hutan Leuweung Gede yang dilakukan secara berkelompok, sehingga karakter mereka meningkat.

Tahap konfirmasi. Dosen memotivasi mahasiswa yang belum aktif supaya mereka lebih baik lagi dalam belajar dengan cara memberikan lembar tugas yang harus dikerjakan secara kelompok. Kegiatan diskusi kelas ini berlangsung selama 20 menit.

Kegiatan penutup. Dosen bersamasama dengan mahasiswa membuat kesimpulan dari materi yang telah diajarkan. Setelah itu dosen menyampaikan tugas kelompok selanjutnya sesuai dengan lembar tugas yang telah disediakan.

Pertemuan ke dua dilaksanakan dengan melalui tahap pendahuluan, kegiatan inti, dan penutup.
Pendahuluan. Dosen melakukan apersepsi selama 5 menit, yaitu memeriksa kehadiran dan kesiapan mahasiswa terutama tugas kelompok yang harus dipresentasikan oleh setiap kelompok. Selanjutnya, dosen menyampaikan motivasi dan tujuan pembelajaran yang harus dicapai oleh mahasiswa setelah mengikuti pembelajaran, yaitu menganalisis niali-nilai kearifan lokal hutan Leuweung Gede.

Kegiatan inti pembelajaran berlangsung selama 60 menit, yaitu tahap eksplorasi, dosen menjelaskan materi secara garis besarnya, kemudian mahasiswa mencari materi dari berbagai sumber yang ada.

Tahap elaborasi. Dosen memfasilitasi terjadinya diskusi kelompok yang diberi kesempatan selama 15 menit untuk mempresentasikan hasil diskusinya. Dalam diskusi ini masih diwakili oleh 2 orang dari tiap kelompok, sedangkan yang lainnya masih berada ditempat duduknya masing-masing untuk membantu menganalisis hasil diskusinya.

Tahap konfirmasi. Dosen memberikan umpan balik positif dan penguatan dalam bentuk lisan bagi mahasiswa yang aktif secara individu maupun kelompok. Memfasilitasi siswa untuk melakukan kuis dengan materi yang sudah didiskusikan.

Kegiatan penutup. Dosen bersamasama mahasiswa menyimpulkan materi yang telah didiskusikan. Selanjutnya dosen memberikan waktu selama 20 menit untuk melakukan post test sebanyak 20 pernyataan angket karakter. Dari perhitungan hasil prestasi siswa pada siklus II diperoleh nilai rata-rata 80 dengan skor terendah 65 dan skor tertinggi 90.

\section{c. Pengamatan}

Berdasarkan hasil pengamatan pada siklus II ini sudah ada peningkatan dibandingkan dengan siklus I, baik dari cara dosen mengajar maupun dari cara 
mahasiswa menanggapi materi. Aktifitas mahasiswa di dalam kelas, seperti antusias dan motivasi siswa belajar sejarah lokal sudah mulai meningkat. Dalam hal memotivsi mahasiswa, dosen telah memberikan arahan dan semangat kepada mahasiswa agar mahasiswa terlibat aktif dalam kegiatan pembelajaran, seperti tidak takut untuk menyampaikan pendapat, serta aktif dalam mencari berbagai sumber yang mendukung dalam proses pembelajaran. Dosen telah memberikan kesempatan kepada mahasiswa untuk menyampaikan pendapat dari permasalahan yang ada, walaupun hanya beberapa mahasiswa yang mau menggunakan kesempatan tersebut. Sebagian besar mahasiswa telah memahami nilai-nilai kearifan lokal dari hutan Leuweung Gede dan kaitannya dengan peningkatan karakter.

\section{d. Refleksi}

Berdasarkan pengamatan pada siklus II, peneliti dan dosen mitra menemukan beberapa masalah, yaitu kekurangan dan hambatan pada pembelajaran siklus II. Kekurangannya terletak pada masih belum efektifnya penggunaan nilai-nilai kearifan lokal, karena terhambat oleh waktu yang tersedia.

\section{Hasil Penggunaan Nilai-Nilai Kearifan Lokal Untuk Meningkatkan Karakter Mahasiswa}

Dalam pembelajaran yang dilaksanakan di tingkat I semester II Prodi Pendidikan Sejarah FKIP, Universitas Galuh, yaitu menggunakan nilai-nilai kearifan lokal hutan Leuweung Gede. Hal ini dapat dilihat pada tabel dan diagram di bawah ini. Rekapitulas hasil angket karakter siklus I, dan siklus II.

\begin{tabular}{ccc}
$\begin{array}{c}\text { Rekapitulasi } \\
\text { mahasiswa: }\end{array}$ & angket & karakter \\
Uraian & Siklus I & Siklus II \\
\hline Rata-rata nilai & 70 & 80 \\
Persentase (\%) & 50 & 80 \\
\hline $\begin{array}{c}\text { Jumlah siswa } \\
\text { tuntas }\end{array}$ & 10 & 16
\end{tabular}

Berdasarkan data di atas menunjukan bahwa dari siklus I ke siklus II mengalami peningkatan karakter mahasiswa, yaitu dari $50 \%$ ke $80 \%$.

\section{KESIMPULAN}

Berdasarkan analisis pada pembahasan, maka dapat ditarik kesimpulan penelitian sebagai berikut:

1. Pelaksanaan penelitian ini direncanakan selama dua siklus. Pada setiap siklus memiliki tahapan perencanaan, pelaksanaan, pengamatan, dan refleksi. Pelaksanaan siklus I diperoleh nilai persentase angket karakter mahasiswa $50 \%$. Pada siklus II diperoleh nilai angket karakter dengan persentase $80 \%$.

2. Dari hasil pengamatan yang dilakukan oleh peneliti karakter mahasiswa mengalami peningkatan. Penggunaan nilai-nilai kearifan lokal hutan Leuweung Gede dapat mempengaruhi karakter mahasiswa tingkat I.

\section{DAFTAR PUSTAKA}

Mulyatiningsih, Endang. (tt). Modul Pelatihan Pendidikan Profesi Guru Fakultas Teknik, Universitas Negeri Yogyakarta Metode Penelitian Tindakan Kelas. http://staffnew.uny.ac.id/upload/131808 329/pengabdian/8cmetode-penelitiantindakan-kelas.pdf. Diakses tanggal 1 Agustus 2020.

Ratih, Dewi dan Suryana, Aan. 2020. NilaiNilai Kearifan Lokal Leuweung Gede Kampung Kuta Ciamis Dalam Mengembangkan Green Bihavior. 
Seminar Nasional Dan Temu Alumni Hmps 2019, 12 Oktober 2019, FIS UNY Yogyakarta.

http://eprints.uny.ac.id/67110/. Diakses tanggal 1 Agustus 2020.

Sumini, Th. Penelitian Tindakan Kelas Dan Pengembangan Profesi Guru. https://www.usd.ac.id/lembaga/lppm/f1 13/Jurnal\%20Historia\%20Vitae/vol24no 1 april2010/PENELITIAN\%20TINDAK AN\%20KELAS\%20Th\%20sumini.pdf. Diakses tanggal 1 Agustus 2020.

Wagiran. 2012. Pengembangan Karakter Berbasis Kearifan Lokal Hamemayu Hayuning Bawanam (Identifikasi NilaiNilai Karakter Berbasis Budaya). Jurnal Pendidikan Karakter Tahun II, Nomor 3, Oktober 2012. Hal. 329-339. 
Jurnal Artefak:

Vol.7 No.2 September 2020 [141-152]

Halaman | 152 